\title{
Possibilities of Leachate Co-Treatment Originating from Biogas Production in the Deammonification Process
}

\author{
Joanna Majtacz'1, Grubba Dominika ${ }^{1 *}$, Przemysław Kowal' ${ }^{1}$, Krzysztof Czerwionka' \\ 1 Faculty of Civil and Environmental Engineering, Gdansk University of Technology, ul. Gabriela Narutowicza 11/12, \\ 80-233 Gdańsk, Poland \\ * Corresponding author's e-mail: dominika.grubba@pg.edu.pl
}

\section{INTRODUCTION}

It is estimated that the amount of sewage sludge generated during the wastewater treatment is about $1-3 \%$ of the volume of wastewater transported to the plant. This amount depends on the composition of the wastewater, treatment technology and the reagents used in the treatment process (Kołodziejczak 2012). Due to the trends of the wastewater treatment process intensification and improvements in terms of system efficiency, it appears necessary to search for rational ways of managing them (Czekała 2012).

In previous years, sewage sludge was mainly stored in municipal landfills. However, in 2016 a ban on their storage was introduced (Regulation of the Minister of Economy 2015) and other solutions that would enable their safe disposal were started to be sought. The high content of organic matter in sewage sludge makes it a valuable fertilizer, but the biological and mineral pollutants, such as heavy metals and pathogenic microorganisms, cause restrictions in their agricultural use. This is mainly due to lower permissible concentrations of heavy metals in sediments, which directs their management by thermal methods.

Therefore, the methane fermentation process in which sewage sludge is the only substrate or serves as a co-substrate with the addition of various waste products turns out to be an important alternative. The process is carried out in separate fermentation chambers. This process allows obtaining stable digestate, which is a safer waste compared to the sewage sludge before fermentation. The content of organic substances decreases by at least $30 \%$; the hydration of the sludge decreases as well, causing an increase in the solids mass in the sludge to 6-7\% (Kołodziejczak 2012). The digestate has a black color due to the content of sulphides and humus substances.

In connection with the hydration of sludge, it is important to subject it to appropriate processes: concentration and dehydration (Sadecka 2014). This reduces the amount of water as well as the volume of sludge and thus increases the dry matter content. After the separation of digestate into solid and liquid fractions, two types of waste are generated 190606 and 190505 (Regulation of the Minister of the Environment on the waste cata$\log$ ). The liquid fraction, called leachate, due to the high content of nutrients, must be purified before it is discharged into the environment. The leachates from excessive sludge dewatering in municipal wastewater treatment plants are characterized by high concentrations of organic substance expressed in COD (approx. $8000 \mathrm{mg} \mathrm{O}_{2} / \mathrm{dm}^{3}$ on average), total suspension (approx. $6000 \mathrm{mg} / \mathrm{dm}^{3}$ on average) and total nitrogen (approx. $1600 \mathrm{mg} / \mathrm{dm}^{3}$ on average), mainly in the form of ammonium nitrogen - $\mathrm{NH}_{4}-\mathrm{N}$ ) (Obarska-Pempkowiak 2009). In addition, these leachates contain toxic refractory compounds, such as BTEX, PAHs, PCBs and heavy metals, as well as high concentrations of iron and chloride (Wojciechowska and ObarskaPempkowiak, 2008). However, the literature does not provide the composition of leachate from a biogas plant, for which the greatest challenge is its proper management. The amount of leachate can be up to $0.83 \mathrm{~m}^{3} / \mathrm{Mg}$ of charge (Jędrczak 2008). Sometimes, the leachate after treatment is directed to water receivers or recycled to the wastewater treatment plant (Czekala 2012). 
There are also solutions that return the leachate to the fermentation chambers. There are no literature reports about their treatment in the process of deammonification.

There are many factors that affect the efficiency of the deammonification process, such as temperature, $\mathrm{pH}$, aeration method, and $\mathrm{C} / \mathrm{N}$ ratio. It was found that the processes of biodegradable COD oxidation as well as anaerobic denitrification occur simultaneously with the deammonification process, which improves the efficiency of total nitrogen removal (Ni et al. 2011, Zhang et al. 2013). Higher values of the $\mathrm{C} / \mathrm{N}$ ratio can lead to denitrification, owing to which the $\mathrm{NO}_{3}-\mathrm{N}$ generated in the anammox process (11\% nitrogen participating in the process) can be converted to $\mathrm{N}_{2}$, thus increasing the efficiency of nitrogen removal. However, excessive COD concentration increases the multiplication of heterotrophic bacteria that compete for nitrite $\left(\mathrm{NO}_{2}-\mathrm{N}\right)$ with anaerobic ammonium oxidizing bacteria (AAOB) and for oxygen with ammonium oxidizing bacteria (AOB), which consequently reduces the efficiency of nitrogen removal (Chen et al. 2009). It was shown that after decreasing the $\mathrm{C} / \mathrm{N}$ ratio from 0.75 to 0.5 , the efficiency of total nitrogen removal increased from $62 \%$ to $70 \%$. On the other hand, Miao et al. (2018) noticed that the efficiency of the partial nitrification/anammox process increased along with the $\mathrm{C} / \mathrm{N}$ ratio. After exceeding this value, the process stopped. Due to the fact that the leachate after the methane fermentation process is characterized by a relatively high content of organic compounds expressed as COD, their co-purification in the deammonification process seems to be a challenge.

The aim of the present study was to determine the possibility of treatment of the leachate from biogas plants using co-fermentation of agricultural products (bovine slurry) and excessive activated sludge in the deammonification process. It is assumed that the process will run efficiently with the appropriate $\mathrm{C} / \mathrm{N}$ ratio in the supplied leachate.

\section{MATERIALS AND METHODS}

\section{Laboratory settings}

The deammonification process was carried out in a laboratory scale in a $10 \mathrm{dm}^{3}$ sequencing batch reactor (SBR). The reactor was inoculated with the biomass from earlier long-term deammonification in the sidestream. The system was equipped with a thermostatic jacket, which aims to maintain a constant temperature of $20 \pm 1^{\circ} \mathrm{C}$. The $\mathrm{pH}$ was measured continuously and controlled in the range of 7.3-7.9 by the addition of 1.0 M NaOH. Constant dissolved oxygen concentration (DO) was measured during the study to control aeration. The reactor operated in cycles consisting of sedimentation, decantation, filling and reaction phases. The reaction phase was divided into 3 min of aeration and 9 min of mixing.

Before each cycle, $4 \mathrm{dm}^{3}$ of synthetic wastewater prepared in accordance with Dapena-Mora et al. (2004) was introduced into the reactor. Then, the leachate from digestate dehydration after the mesophilic co-fermentation process of the feed including bovine slurry and excessive active sludge was added in a weight ratio of 1:3. Leachates were added to maintain a $\mathrm{C} / \mathrm{N}$ ratio of 1 , as preliminary studies had shown that such conditions do not have a negative effect on the deammonification. The digestate dehydration was carried out by centrifugation on a laboratory centrifuge (Jouan B4i) for $30 \mathrm{~min}$ at $4000 \mathrm{rpm}$. In order to remove the suspension fraction, the leachates were previously filtered through nitrocellulose membrane filters with a pore size of $1.2 \mu \mathrm{m}$ before entering the system (Whatman, Kent, UK). At the end of the study, in order to further reduce the concentration of organic matter (COD), Superfloc C494VP polyelectrolyte (Kemira) was dosed into the leachate at a dose of $0.5 \mathrm{mg} / \mathrm{dm}^{3}$. The sample was mixed intensively for $0.5 \mathrm{~min}$ and slowly for $30 \mathrm{~min}$, and then again centrifuged on a laboratory centrifuge while maintaining the previous conditions for carrying out this process.

\section{Analytical methods}

The efficiency of the deammonification system was assessed during 6-hour tests by analyzing the variability of $\mathrm{NH}_{4}-\mathrm{N}, \mathrm{NO}_{2}-\mathrm{N}, \mathrm{NO}_{3}-\mathrm{N}$ and COD concentrations. The $\mathrm{NH}_{4}-\mathrm{N}, \mathrm{NO}_{2}-\mathrm{N}, \mathrm{NO}_{3}-\mathrm{N}$ and $\mathrm{COD}$ concentrations were determined spectrophotometrically by the use of cuvette tests (Hach Lange GmbH). The total biomass concentration as total solids suspension (TSS) and organic biomass fraction as volatile solid suspension (VSS) were determined in accordance with standard methods (APHA, 2005).

Ammonium utilizing rate (AUR), nitrogen production rate (NPR) and anammox activity 
(AA) were calculated to evaluate the deammonification process based on the formulas below:

AUR calculated from the formula (1):

$$
\mathrm{AUR}=\frac{\mathrm{SNH} 4-\mathrm{N}, \mathrm{t} 1-\mathrm{SNH} 4-\mathrm{N}, \mathrm{t} 2}{(\mathrm{t} 2-\mathrm{t} 1) \cdot \mathrm{X}} \mathrm{mg} \mathrm{N} /(\mathrm{g} \text { vss} \cdot \mathrm{h})
$$

NPR calculated from the formula (2):

$$
\mathrm{NPR}=\frac{\mathrm{SNO} 3-\mathrm{N}, \mathrm{t} 2-\mathrm{SNO} 3-\mathrm{N}, \mathrm{t} 1}{(\mathrm{t} 2-\mathrm{t} 1) \cdot \mathrm{X}} \mathrm{mg} \mathrm{N} /(\mathrm{g} \text { vSs } \cdot \mathrm{h})
$$

AA calculated from the formula (3):

$$
\begin{gathered}
\mathrm{AA}=\frac{(\mathrm{SNH} 4-\mathrm{N}, \mathrm{t} 1+\mathrm{SNO} 3-\mathrm{N}, \mathrm{t} 1)-(\mathrm{SNH} 4-\mathrm{N}, \mathrm{t} 2+\mathrm{SNO} 3-\mathrm{N}, \mathrm{t} 2)}{(\mathrm{t} 2-\mathrm{t} 1) \cdot \mathrm{X}} \\
\mathrm{mg} \mathrm{N} /(\mathrm{g} \mathrm{vSS} \cdot \mathrm{h})
\end{gathered}
$$

$S_{N H 4-N^{\prime} t}-$ ammonium nitrogen concentration after $\mathrm{t}_{1}$ or $\mathrm{t}_{2}, \mathrm{mg} \mathrm{N} / \mathrm{dm}^{3}$

$S_{\text {NO3-N't }}$ - nitrate nitrogen concentration after $\mathrm{t}_{1}$ or $\mathrm{t}_{2}, \mathrm{mg} \mathrm{N} / \mathrm{dm}^{3}$

$t$-start $\left(t_{1}\right)$ and end $\left(t_{2}\right)$ time of measurement, $\mathrm{h}$

$X$ - concentration of activated sludge organic fraction, $\mathrm{g} \mathrm{mlvss} / \mathrm{dm}^{3}$.

\section{RESULTS AND DISCUSSION}

The concentrations of selected parameters in digestate dehydration leachates are presented in Table 1.

The efficiency of the deammonification process was tested by measuring the AUR, NPR, NPR / AUR and AA values. The values of these parameters in the following days of testing are summarized in Table 2.

In the studies, from $1^{\text {st }}$ to $14^{\text {th }}$ day of the test, the AUR rate dropped from 3.4 to $2.9 \mathrm{mg} \mathrm{N} /(\mathrm{g}$ vss $\bullet \mathrm{h})$ due to the high content of COD suspension fraction in the leachate and its adverse effect on the anammox bacteria activity. From the $22^{\text {nd }}$ day, when the leachate was treated by polyelectrolyte addition, the AUR rate almost doubled to $5.4 \mathrm{mg} \mathrm{N} /(\mathrm{g}$ vss $\bullet \mathrm{h})$, which was the result of over $40 \%$ improvement of efficiency in removing the organic fraction suspension. Longer dosing of leachate containing overdosed polyelectrolyte resulted in a further decrease in AUR to $3.8 \mathrm{mg} \mathrm{N} /(\mathrm{g}$ vss $\bullet \mathrm{h})$. Most likely, this was due to the polyelectrolyte interaction with the sludge flocs and their mutual sticking. Compared to synthetic sewage, the AUR values in our study were about three times higher, because Al-Hazmi et al. (2019) state that with a $\mathrm{C} / \mathrm{N}$ ratio of 1 , the AUR values change in the range of $1-1.5 \mathrm{mg} \mathrm{N} /(\mathrm{g}$ MLVSS • h).

It was also observed that the NPR value in the following days of the study gradually increased from 1.8 to $1.9 \mathrm{mg} \mathrm{N} /(\mathrm{g}$ vss $\bullet h)$ and on the $22^{\text {nd }}$ day, it suddenly increased to $2.5 \mathrm{mg} \mathrm{N} /(\mathrm{g}$ vss $\bullet \mathrm{h}$ ). Such results indicate a greater activity of nitrogen oxidizing bacteria (NOB) under the obtained conditions; however, it turns out that the rate of NPR on that day was due to the decidedly higher AUR rate. The aforementioned dependencies are observed in Fig. 1, which graphically presents the changes in the AUR, NPR and NPR/AUR values in the following days of the study.

The changes in the values of the AUR and NPR parameters simultaneously translated into the NPR/AUR ratio. This value increased from 0.53 to 0.66 during the course of the test without the addition of polyelectrolyte, which was due to the decrease in AA caused by the aforementioned amount of COD suspension fraction in the leachate. After dosing the leachate with polyelectrolyte, the NPR/AUR value dropped to 0.37 , which indicates an improvement in AA due to a decrease in the $\mathrm{C} / \mathrm{N}$ ratio. In parallel, however, it was noted that the granules began to stick together and the process could not run correctly. The confirmation of this phenomenon is also the AA variability graph since time presented in Figure 2.

AA fell steadily during the following days of the study. On the $1^{\text {st }}$ day it was $14.4 \mathrm{~g} / \mathrm{m}^{3}$, while on the last day it amounted to $10.6 \mathrm{~g} / \mathrm{m}^{3}$. In the first weeks, one can notice a much faster drop in AA compared with the following days. This is due to the suspension remaining in the leachate. After the addition of polyelectrolyte, some AA stabilization

Table 1. Average pollutant concentrations in the effluent from dehydration of digestate formed during the cofermentation of excessive activated sludge and bovine slurry

\begin{tabular}{|l|c|c|c|c|}
\hline \multirow{2}{*}{\multicolumn{1}{|c|}{ Leachates }} & \multicolumn{4}{c|}{ Quality parameters. $\mathrm{mg} / \mathrm{dm}^{3}$} \\
\cline { 2 - 5 } & $\mathrm{COD}$ & $\mathrm{COD}_{\mathrm{f}}$ & $\mathrm{TN}$ & $\mathrm{NH}_{4}-\mathrm{N}$ \\
\hline Without dosing polyelectrolyte & $5203 \pm 329.9$ & $2717.5 \pm 38.7$ & $1702.9 \pm 54.6$ & $1565.0 \pm 38.7$ \\
\hline After dosing polyelectrolyte & $4130 \pm 134.1$ & $2670.3 \pm 50.6$ & $1631.4 \pm 42.7$ & $1552.7 \pm 29.6$ \\
\hline
\end{tabular}


Table 2. AUR, NPR and NPR / NPR values on subsequent days of the study

\begin{tabular}{|c|c|c|c|c|}
\hline Day & $\begin{array}{c}\text { AUR } \\
\text { [mg N/ (g } \\
\text { vss } \cdot h)\end{array}$ & $\begin{array}{c}\text { NPR } \\
\text { [mg N/ (g } \\
\text { vss } \cdot h)\end{array}$ & NPR/AUR & $\begin{array}{c}\text { AA } \\
\text { [mg N/ (g } \\
\text { vss } \cdot h)\end{array}$ \\
\hline 1 & 3.4 & 1.8 & 0.53 & 14.4 \\
\hline 7 & 2.8 & 1.9 & 0.68 & 12.3 \\
\hline 14 & 2.9 & 1.9 & 0.66 & 11.5 \\
\hline $22^{*}$ & 5.4 & 2.5 & 0.46 & 10.7 \\
\hline $27^{*}$ & 3.8 & 1.4 & 0.37 & 10.6 \\
\hline
\end{tabular}

* after adding leachate with polyelectrolyte

occurred; however, additional research that would confirm the absence of a negative effect on AA in the long term is required. Moreover, in the study of Miao et al. (2018), the anammox activity increased along with the $\mathrm{C} / \mathrm{N}$ ratio. Perhaps a slight increase in the $\mathrm{C} / \mathrm{N}$ ratio in our study would benefit the behavior of anammox activity.

Figures 3 and 4 show the changes in $\mathrm{NH}_{4}^{-}$ $\mathrm{N}, \mathrm{NO}_{3}-\mathrm{N}, \mathrm{NO}_{2}-\mathrm{N}$ and $\mathrm{COD}$ values during the 7-hour tests performed on the $1^{\text {st }}$ (Fig. 1) and $27^{\text {th }}$ (Fig. 2) of the test day.
The graphs presented above clearly show the increase in COD after adding leachate with polyelectrolyte. On the $1^{\text {st }}$ day, $13.7 \mathrm{mg}$ of $\mathrm{COD} / \mathrm{dm}^{3}$ was removed within $7 \mathrm{~h}$, while on the last day, only $4.6 \mathrm{mg}$ of $\mathrm{COD} / \mathrm{dm}^{3}$ was eliminated at the same time, while Miao et al. (2018) removed $45 \mathrm{mg}$ of COD $/ \mathrm{dm}^{3}$ in their study within $5 \mathrm{~h}$. On the graphs it can be seen that on the first day after 7 hours, $20.6 \mathrm{mg} \mathrm{COD} / \mathrm{dm}^{3}$ remains, and on the $27^{\text {th }}$ day $-54 \mathrm{mg}$ of $\mathrm{COD} / \mathrm{dm}^{3}$. It follows that the COD removal efficiency was about $40 \%$ and $3.4 \%$ on the first and the last day, respectively. This situation may be caused by the accumulation of hardly degradable COD in the reactor, as a result of removal from the leachate of a part of the slow degradable COD fraction due to the action of polyelectrolyte. For comparison, the COD removal efficiency in the study by Miao et al. (2016) after a 5-hour cycle was about $25 \%$. The $\mathrm{NH}_{4}-\mathrm{N}$ removal efficiency in our study was about $100 \%$. In the study of Bi et al. (2015), this value was about $33 \%$ in an 8 -hour cycle. Moreover, an increase in the $\mathrm{NO}_{3}-\mathrm{N}$ concentration can also be seen. The $\mathrm{NO}_{3}-\mathrm{N}$ production was about $65 \%$ and

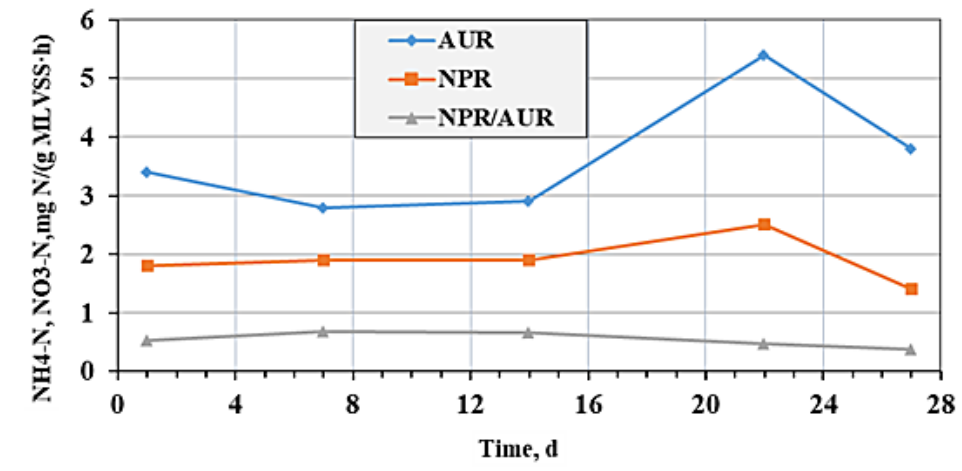

Fig. 1. AUR, NPR and NPR/AUR values on subsequent days of the study

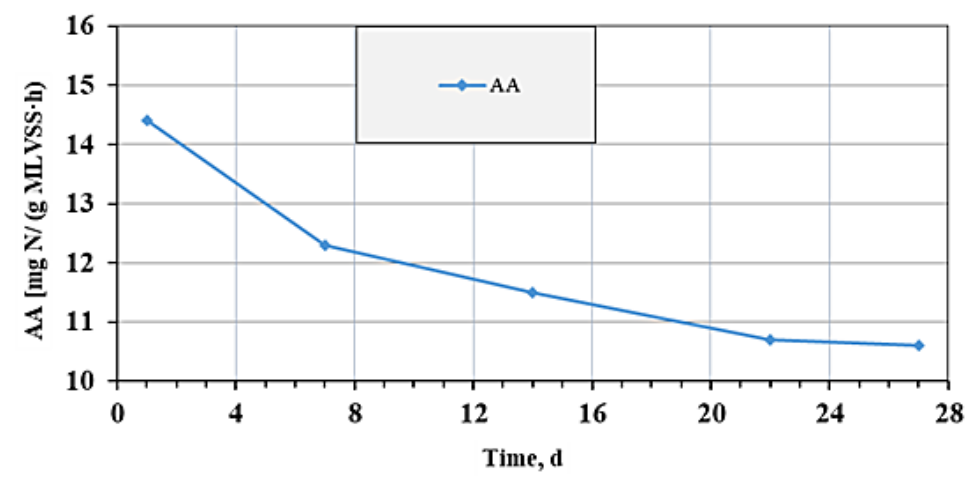

Fig. 2. AA changes during research 


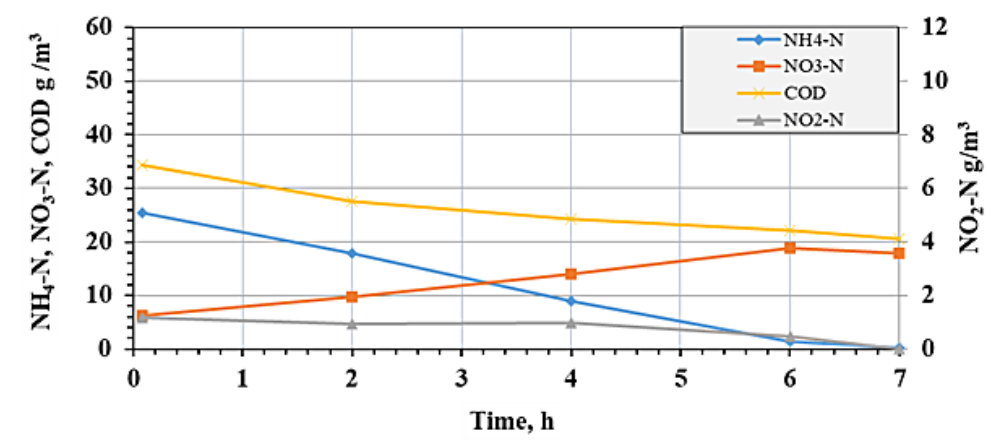

Fig. 3. $\mathrm{NH}_{4}-\mathrm{N}, \mathrm{NO}_{3}-\mathrm{N}, \mathrm{NO}_{2}-\mathrm{N}$ and $\mathrm{COD}$ values during 7-hour tests on the $1^{\text {st }}$ day of the study

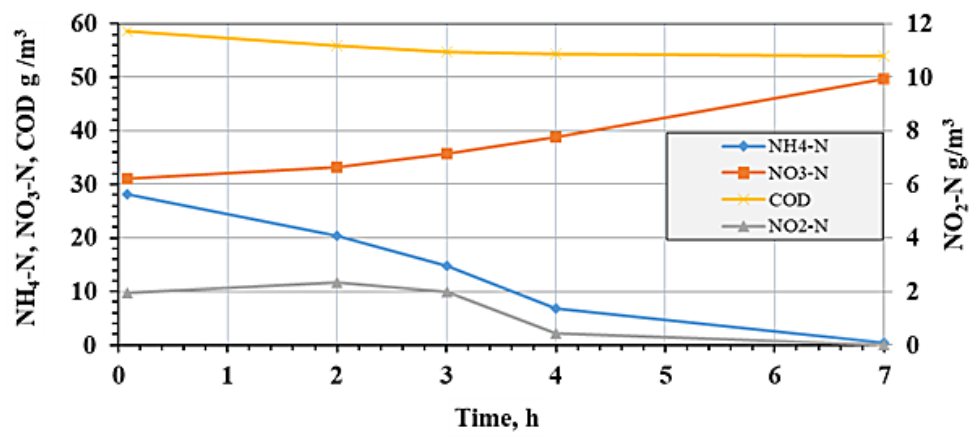

Fig. 4. $\mathrm{NH}_{4}-\mathrm{N}, \mathrm{NO}_{3}-\mathrm{N}, \mathrm{NO}_{2}-\mathrm{N}$ and $\mathrm{COD}$ values during 7 -hour tests on the $27^{\text {th }}$ day of the study

about $33 \%$ on the first and last day, respectively, while it was $25 \%$ in the study of Miao et al. (2016) after a $5 \mathrm{~h}$ cycle. Moreover, This may also be the result of the removal of slowly degradable organic compounds and the presence of a large amount of hardly degradable carbon compounds that cannot be used in the denitration process during which the remaining $\mathrm{NO}_{3}-\mathrm{N}$ is converted to $\mathrm{N}_{2}$ gas.

\section{CONCLUSIONS}

The conducted experiments revealed the potential of the leachates from biogas plants cotreatment for the deammonification process. However, the share of leachate in the feed solution should be determined individually for each type of substrate after previous COD concentration analyses. Stable deammonification performance was obtained for the $\mathrm{C} / \mathrm{N}$ ratio $1: 1$. The experiment reflected that the oxidation of $\mathrm{NH}_{4}-\mathrm{N}$ can be enhanced by polyelectrolyte addition. On the other hand, long term addition of the Superfloc C494VP (from Kemira) to leachates negatively affected the viscosity of the granulated biomass responsible for deammonifiaction process and their sticking, which had a negative impact on the process rates. In the near future, it is planned to continue the research on leachate treatment from methane fermentation, taking into account the possibility of improving suspensions separation by means of alternative methods.

\section{Acknowledgments}

This study was financially supported by European Regional Development Fund within the framework of Smart Growth Operational Programme 2014-2020 under the project no POIR.04.01.02-00-0022/17.

\section{REFERENCES}

1. Al-Hazmi H, Grubba D, Majtacz A, Kowal P, Mąkinia J. 2019. Evaluation of deammonification process performance and microorganisms community composition under different $\mathrm{C} / \mathrm{N}$ ratio (in progress).

2. Bi Z, Takekawa M, Park G, Soda S, Zhou J, Qjao S, Ike M. 2015. Effects of the $\mathrm{C} / \mathrm{N}$ ratio and bacterial populations on nitrogen removal in the simultaneous anammox and heterotrophic denitrification process: Mathematic modeling and batch experiments. Chemical Engineering Journal, 280, 606-613. 
3. Chen H, Liu S, Yang F, Xue Y, Wang T. 2009. The development of simultaneous partial nitrification, ANAMMOX and denitrification (SNAD) process in a single reactor for nitrogen removal. Bioresour. Technol., 100, 1548-1554.

4. Czekała W, Pilarski K, Dach J, Janczak D, Szymańska M. 2012. Analiza możliwości zagospodarowania pofermentu $\mathrm{z}$ biogazowni [Analysis of management possibilities for digestate from biogas plant]. Technika Rolnicza Ogrodnicza Leśna, 4, 13-15.

5. Dapena-Mora A, Arrojo B, Campos JL, MosqueraCorral A, Méndez R. 2004. Improvement of the settling properties of Anammox sludge in an SBR. J. Chem. Technol. Biotechnol., 79, 1417-1420.

6. Jędrczak A. 2008. Biologiczne przetwarzanie odpadów [Biological waste treatment]. Wydawnictwo Naukowe PWN Warszawa.

7. Kołodziejczak G. 2012, Możliwości wykorzystania potencjału energetycznego biogazu powstającego w trakcie procesu oczyszczania ścieków. Analiza opłacalności proponowanych rozwiązań [Possibilities of using the energy potential of biogas generated during the wastewater treatment process. Analysis of the profitability of the proposed solutions]. Nafta Gaz, 12, 1036-1043.

8. Miao Y, Peng Y, Zhang L, Li B, Li X, Wu L, Wang S. 2018. Partial nitrification-anammox (PNA) treating sewage with intermittent aeration mode: Effect of influent $\mathrm{C} / \mathrm{N}$ ratios. Chem. Eng. J., 334, 664-672.

9. Miao Y, Zhang L, Yang Y, Peng Y, Li B, Wang S, Zhang Q. 2016. Start-up of single-stage partial nitrification-anammox process treating low-strength swage and its restoration from nitrate accumulation. Bioresource Technology, 218, 771-779.

10. Ni BJ, Ruscalleda M, Pellicer-Nàcher C, Smets BF. 2011. Modeling nitrous oxide production during biological nitrogen removal via nitrification and denitrification: extensions to the general ASM models. Environ Sci Technol, 45, 7768-7776.

11. Obarska-Pempkowiak H, Gajewska M, Wojciechowska E. 2009. Koncepcja oczyszczania odcieków o wysokich stężeniach zanieczyszczeń metodą hydrofitową [The concept of purification of leachates with high concentrations of impurities using the hydrophyte method]. Monografie Komitetu Inżynieria Środowiska PAN, 61(4), 9-18.

12. Płatek W. 2007. Biomasa W energetyce rozproszonej - biogazownie energetyczne [Biomass in dispersed energy - energy biogas plants]. Czysta energia, 1, 28-29.

13. Rozporządzenie Ministra Gospodarki z dnia 16 lipca 2015 r. w sprawie dopuszczania odpadów do składowania na składowiskach [Regulation of the Minister of Economy of 16th July 2015 on the admission of waste for landfill]. Dz.U. 2015 poz. 1277.

14. Rozporządzenie Ministra Środowiska z dnia 27 września 2001 r. W sprawie katalogu odpadów [Regulation of the Minister of Environment of 27th September 2001 regarding the waste catalog]. Dz.U. 2001 nr 112 poz. 1206.

15. Sadecka Z. Przyrodnicze zagospodarowanie osadów ściekowych. W: Metody zagospodarowania osadów ściekowych [Environmental management of sewage sludge. In: Management methods of sewage sludge]. Materiały konferencyjne, 2-3 czerwca 2014, Zielona Góra, 11-22.

16. Szlachta J. 2009. Ekspertyza. Możliwości pozyskiwania biogazu rolniczego jako odnawialnego źródła energii [Expertise. Possibilities of acquiring agricultural biogas as a renewable energy source]. AgEngPol 2009, 1-9.

17. Wojciechowska E, Obarska-Pempkowiak H. 2008. Leachate treatment at a pilot plant using hydrophyte systems; in: Management of Pollutant Emission from Landfills and Sludge, ed. Pawłowska M, Pawłowski L, Taylor and Francis.

18. Zhang X, Li D, Liang Y, He Y, Zhang Y, Zhang J. 2013. Autotrophic nitrogen removal from domestic sewage in MBR-CANON system and the biodiversity of functional microbes. Bioresour Technol, $150,113-120$. 